\title{
THE ROLE OF ANTIOXIDANTS IN INDUCING WHEAT FLAG LEAF OSMOTIC ADJUSTMENT UNDER SALINITY STRESS
}

Gadalla, S. F.

Agric. Botany Dept., Faculty of Agric., Mansoura Univ., Mansoura, Egypt. Email: gadalla@mans.edu.eg

\begin{abstract}
Salt stress up to $11.5 \mathrm{dSm}^{-1}$ causes a significant reduction in water potential, osmotic potential, as well as relative water content, and water content. On the other hand, turgor potential and osmotic adjustment were significantly increased due to inducing increasing the higher accumulation of compatible osmolytes which leads to decreasing flag leaf area and grain yield per plant. Application of both antioxidants, in particular, ascorbic acid increased significantly flag leaf area, and grain yield per plant due to osmotic adjustment and maintaining leaf turgor potentials as a consequence of increasing leaf water potential, water content and relative water content as compared to control plants. On the other hand, application of both antioxidants under all salinity levels, nullify the harmful effect of salinity effects on flag leaf area and grain yield per plant due to increasing osmolyte accumulation, maintaining turgor potential and osmotic adjustments which in turn increasing flag leaf area and grain yield per plant.

Anatomically, increasing salinity levels decreased thickness of leaf blade at midrib region, thickness of mesophyll tissue, tangential dimension of midrib vascular bundle, thickness of upper epidermis, thickness of lower epidermis, thickness of big motor cell, and tangential dimension of big xylem vessel. Treatment with either ascorbic acid or tocopherol at $100 \mathrm{mg} / \mathrm{L}$ and their interactions with salinity increased all the above mentioned parameters in both nonsalinized and salinized plants. Ascorbic acid is the most effective in this concern. In conclusion, wheat plants responded to an increased ion influx in their cells by increasing the osmolytes synthesis and accumulation under salt stress, which further increased with antioxidants treatment and helped in maintaining the osmotic balance.
\end{abstract}

Keywords: Ascorbic, tocopherol, soil salinity, growth, yield, wheat

\section{INTRODUTION}

Soil Salinization is one of the major factors of soil degradation. It has reached $19.5 \%$ of the irrigated land and $2.1 \%$ of the dry-land agriculture existing on the globe. Salinity problem considered a significant factor affecting plant production and agricultural sustainability in many regions of the world as it reduces the value and productivity of the affected land. In most saline soils $\mathrm{Na}^{+}$and $\mathrm{Cl}^{-}$are the dominant ions, and usually they exceed by far the plant demand/necessity. The excess of soluble salts in the root environment alter the aqueous and ionic thermodynamic equilibrium, which results in hyper-osmotic stress, ionic imbalance and toxicity (Munns, 2002). As a result of these changes, the activities of various enzymes and the plant metabolism are affected (Munns, 2002; Lacerda et al., 2003). Thus, the exposed plants have to minimize water loss and thereby maintain a favorable water status for development (Sohan et al., 1999). Many plants are able to tolerate saline stress by reducing the cellular osmotic potential as a consequence of a net increase in solute accumulation, in a process called 
osmotic adjustment (Munns, 2002; Serraj and Sinclair, 2002). Osmotic adjustment $(\mathrm{OA})$ is usually achieved by uptake of inorganic ions i.e. $\mathrm{K}^{+}, \mathrm{Na}^{+}$ and $\mathrm{Cl}^{-}$from the soil solution or synthesizing and accumulation of organic compounds as sugars (Farouk, 2005), and amino acids, mainly proline (Verslues and Sharp, 1999). Energy is needed for the synthesis or transport of solutes for osmotic adjustment (Munns, 2002). Taking into consideration energy efficiency, it is predicted that the accumulation of ions, which is not needed in the metabolism and is of low molecular weight, is efficient for the $\mathrm{OA}$, and that the ions can be accumulated quickly in response to osmotic stress (Raven 1985). However, the excessive accumulation of ions may disrupt the balance of the absorption and the function of other ions in the cell.

In mature leaf, OA plays an important role for plant cell survival, facilitative higher stomatal conductance and leaf expansion (Westgate and Boyer 1985) to sustain photosynthesis under stress conditions. It is accepted that during osmotic adjustment the cells tend to compartmentalize most of the absorbed ions in vacuoles at the same time that they synthesize and accumulate compatible organic solutes in the cytoplasm in order to maintain the osmotic equilibrium between these two compartments (Hasegawa et al., 2000). As a consequence of solute accumulation, the osmotic potential of the cell is lowered, this, in turn, attracts water into the cell and, thereby, tends to maintain its turgor. In fact, $\mathrm{OA}$ is an effective component of salt tolerance, which has a positive direct or indirect effect on plant productivity, because it contributes to the maintenance of turgor and cell volume (Ludlow and MuChow 1990). The reaction of different wheat cultivars to salt stress with respect to accumulation organic and inorganic solutes is different. In addition, there are some constricting reports regarding to the pattern of these osmotica and their contribution to osmotic adjustment.

The accumulation of compatible solutes that are non-toxic at high concentrations; compatible solutes are defined as water-soluble organic compounds of a low molecular weight (termed also as osmoprotectants) (Chen and Murata, 2002). Moreover, natural osmoprotectant concentrations in cytoplasmic compartments are osmotically significant because they have pivotal roles in maintaining cell turgor and the driving gradient for water uptake under stress (Rontein et al., 2002), allowing physiological processes, such as stomatal opening, photosynthesis and cell expansion (Serraj and Sinclair, 2002). In addition to their role in cell water relations, organic solutes accumulation may also help towards the maintenance of ionic homeostasis and of the $\mathrm{C} / \mathrm{N}$ ratio, removal of free radicals, and stabilization of macromolecules and organelles, such as proteins, protein complexes and membranes (Bray et al., 2000). In plant the major compatible osmoprotectant solutes are glycinebetaine and proline (Misra and Gupta, 2005) are thought to function as osmoprotectants for protein (Bohnert and Jenson, 1996) these solutes also provide a protective environment for enzymes and macromolecular structure and function. The contributory role of osmoprotectants i.e. glycinebetaine and proline to osmotic adjustment under salt stress was confirmed by several investigations (Yeo, 1998; Meloni et al., 2001), but the significance of its osmotic adjustment is still in debate and varies according to the species. Hence, improvement of crop performance by 
increasing osmotic potential-adjusting ability might be more significant in increasing plant growth and yield. Osmotic adjustment may be achieved by application of some osmoprotectants, ions, plant growth substances (Farouk, 2005) and finally by antioxidants, but there are few report in this respect. OA leads to better extraction of water from the soil, maintain the volume of protoplast and turgor pressure, stimulates root growth (Leport et al., 1999) and facilitates a better translocation of pre-anthesis carbohydrates reserves to the grain during the grain filling periods (Subbarao et al., 2000b). Additionally, there is a positive relationship between $O A$ and grain yield in water-deficit environments (Tangpremsri et al., 1995, Blum et al., 1999). Many reports regard OA to be a causal mechanism favoring crop productivity under salinity stress. However, there are also conflicting reports indicating a negative relationship between $\mathrm{OA}$ and seed yield under stress condition (Subbarao et al., 2000a). Other reports indicate no relationship between OA and growth and/or seed yield under stress condition (Tangpremsri et al., 1995). Thus, $O A$ as an adaptation mechanism for salinity resistance is somewhat debatable (Munns 1988) and requires further analysis.

Recently, application of antioxidants has been reported to successfully mitigate the adverse effects of salinity on plants (Beltagi, 2008). Of these, application of antioxidants has recently gained a ground as a very promising means of mitigating the adverse effects of salt on plant growth and metabolism (Shalata and Neumann, 2001). Although the role of antioxidants in improving plant water relations and osmotic adjustment is very rare. Ascorbic acid (AsA) is exceptional antioxidants that react with oxidizing agents much more readily than anything else and mops them up before they have a chance to damage anything (Foyer, 1993). It is a strong reducatant that services in cells as electron donor, reducing and thus, running the risk of many different compounds (Smirnoff, 1996). Much evidence has suggested that AsA affects biosynthesis, levels and signaling of many phytohormones including ethylene, gibberellic acid and abciscic acid. Therefore, AsA has proposed roles in regulating many physiological and developmental processes including photosynthesis, cell division and growth, flowering and senescence (Barth et al., 2006). Many studies indicate that foliar application of AsA exerted positive effects on leaves content of photosynthetic pigments, growth and yield of many plants (Singh et al., 2001; Talaat, 2003).

Tocopherols are believed to protect chloroplast membranes from photo-oxidation and help to provide an optimal environment for the photosynthetic machinery. Most of proposed tocopherols functions are related to their antioxidant properties, the most prominent of which is protection of polyunsaturated fatty acids from lipid peroxidation by quenching and scavenging various reactive oxygen radicals. Also, in plants, tocopherol levels vary in different tissues and fluctuate during development and in response to a biotic stress. Tocopherols and its effect on growth and metabolism of plants and its role in amelioration of plants against stresses were studied by many authors i.e. Jahnke and White (2003), and Hussein et al. (2007). 
Gadalla, S. F.

In spite of these controversies, osmotic adjustment is receiving increasing recognition as a major plant acclimatization mechanism to salt stress (Misra and Gupta 2005). Several ions, amino acids, quaternary amines, organic acids, and sugars were found among the solutes that accumulate during osmotic adjustment of salt stressed plants (Meloni et al., 2001). Antioxidants can play an important role in the development of salt tolerance in crops. However, there is little information about the role of antioxidants on regulation of osmotic adjustment processes in plants under normal or salinized condition. Therefore, the main objective of the present study was to test the hypothesis that are the application of antioxidants improving wheat grain yield under salinity is due to improvement plant water relations and osmotic adjustment processes.

\section{MATERIALS AND METHODS}

Fifteen uniform wheat grains (Giza 168 cultivar) were sown on $10^{\text {th }}$ November, 2006 and $15^{\text {th }}$ November, 2007 (First and second season, respectively), in closed-bottom plastic pots containing $15 \mathrm{~kg}$ clay loam soil, (containing $0.786 \mathrm{meq} / 100 \mathrm{~g}$ soil sulphate, $0.27 \mathrm{meq} / 100 \mathrm{~g}$ bicarbonate, 0.51 $\mathrm{meq} / 100 \mathrm{~g}$ chloride, $0.38 \mathrm{meq} / 100 \mathrm{~g}$ calcium, $0.60 \mathrm{meq} / 100 \mathrm{~g}$ magnesium, $0.006 \mathrm{meq} / 100 \mathrm{~g}$ potassium and $0.45 \mathrm{meq} / 100 \mathrm{~g}$ sodium) with or without additional salinity. Soils were salinized prior to sowing by adding sodium chloride $(\mathrm{NaCl})$ solution to adjust salt concentrations to $0.12,0.35$ and $0.70 \%$ $\mathrm{NaCl}$ of oven dry soil. Actual salinity levels expressed as ECe $\left(\mathrm{dSm}^{-1}\right)$ were determined at three times before and during cultivation. The means of salinity levels in soil were $0.8,7.5$ and $11.5 \mathrm{dSm}^{-1}$.

Two weeks after sowing, the seedlings were thinned to 10 uniform seedlings per pot. Phosphorous and potassium fertilizers were added to the soil before sowing at the rate of $5 \mathrm{~g} \mathrm{P}_{2} \mathrm{O}_{5}$ per pot in the form of calcium super phosphate $\left(15.5 \% \mathrm{P}_{2} \mathrm{O}_{5}\right)$ and $2 \mathrm{~g} \mathrm{~K} 2 \mathrm{O}$ per pot in the form of potassium sulphate (48\%). Ammonium nitrate $(33.5 \%)$ was added at the rate of $4 \mathrm{~g}$ $\mathrm{N} /$ pot in two equal portions; the first during the seedling stage and the second at the appearance of the flag leaf. At 40 days from sowing, the pots at each salinity levels were divided into three groups. The first group was sprayed twice with water (control), while the other two groups were sprayed twice (i.e. after 40 and 50 DFS) with aqueous solutions of either ascorbic or $\alpha$ tocopherol at the rate of $100 \mathrm{mg} / \mathrm{l}$ until run-off, with Tween 20 as a wetting agent. At heading (65 DFS), three randomly selected plants were harvested per pot and then removed for determination of flag leaf area and biochemical constituents. Flag Leaf Area $\left(\mathrm{cm}^{2}\right)$ which was calculated by the following formula; $\mathrm{a}=\mathrm{L} \times \mathrm{W} \times 0.75$ (Gardner et al., 1985).

Flag leaf Water relations parameters and osmotic adjustment: Quantification of flag leaf water status was made by measuring the leaf water relations parameters; water content (WC), relative water content (RWC), water potential (WP), osmotic potential (OP), turgor potential, and osmotic adjustment $(\mathrm{OA})$ during the crop productive phase at early flowering (65 DAS). Water content was determined according to Fernandez-Ballester et.al. 
(1998). Meanwhile the relative water content (RWC) was determined, briefly, flag leaf discs were weighted to obtain fresh weight (FW). The plant materials were floated in distilled water inside a closed Petri dish and determined the turgid weight (TW), and then the plant materials were placed in a pre-heated oven at $80^{\circ} \mathrm{C}$ for determination dry weight (DW). RWC $(\%)=\{(\mathrm{FW}-\mathrm{DW}) /$ $(T W-D W)\} \times 100$. Leaf WP $\left(\Psi_{\mathrm{w}}\right)$ was determined according to the method of Taiz and Zeiger (1998). A proportion of the same leaves used for water potential, was divided into two portion, the first portion composed have of lamina (without the midrib vine) that used for determination of osmotic pressure, meanwhile the second portion having lamina with midrib vein that used for measuring osmotic pressure at turgidity. Osmotic potential $\left(\Psi_{0}\right)$ was determined using total soluble solids percentage (TSS) in leaf sap using hand refracto-meter and the corresponding values of water potential were then obtained from tables given by Gossev (1960). The leaves were directly taken from different treatments, immediately frozen for 2 weeks, after which time plant material was thawed and the frozen sap was extracted in the laboratory by crushing the material with pestle. After filtration, the sap was directly used for osmotic pressure determination through determination TSS values then converted to OP from Gossev table. The remaining half from different treatments was immediately placed in a suitable container, with distilled water for $12 \mathrm{~h}$. The sap was then extracted in the laboratory. The TSS at full turgor converted to OP from Gossev table. The osmotic adjustment (OA) is determined using the following equation according to Kiani et al. (2007) $\mathrm{OA}=\Psi \mathrm{FT}(\mathrm{ww})-\mathrm{\Psi FT}(\mathrm{ws})$, where $\Psi \mathrm{FT}(\mathrm{ww})$ is osmotic pressure at full turgor of unstressed plants and $\Psi F T$ (ws) is osmotic pressure at full turgor of stressed plants or antioxidant treated plants. Turgor potential $\left(\Psi_{p}\right)$ was calculated as the difference between leaf water potential and osmotic potential values.

Total free amino acids were extracted and determined according to the modified method of Dubey and Rani (1989a, b). A known weight of dry material was extracted in $80 \%$ ethanol and filtration. To $0.1 \mathrm{ml}$ of this extract was added $5 \mathrm{ml}$ ninhydrin reagent. Contents were shaken vigorously and heated for $10 \mathrm{~min}$ in a boiling water bath. After cooling, absorbance was recorded at $570 \mathrm{~nm}$ in spectrophotometer. Proline was determined by the modified ninhydrine methods of Magne and Larher (1992). Plant materials were placed into test tube containing distilled water. The tubes were kept for $30 \mathrm{~min}$ in a boiling water bath then cooled at room temperature. To $150 \mu \mathrm{L}$ of the corresponding water extract, $1 \mathrm{ml}$ of ninhydrine reagent was added and maintained in a boiling water bath for $20 \mathrm{~min}$. the mixture was cooled and the product formed was extracted with toluene. Absorbance was measured at $520 \mathrm{~nm}$ on a spectrophotometer. A calibration curve was made with L-proline as a standard. Glycine betaine content (GlyBet) content was estimated by the method of Grieve and Grattan (1983). Leaves were weight and oven dried at $75^{\circ} \mathrm{C}$, the dried leaves were finally ground with deionized water at $100{ }^{\circ} \mathrm{C}$ for 60 min. GlyBet concentration was determined spectrophotometrically (Spekol-11) at $365 \mathrm{~nm}$. Total water soluble organic acids (TWSOA) extraction was performed according the methods of Huang and Redmann (1995) using 
Gadalla, S. F.

water: methanol/chlorophorm (2:1): water, and Chloroform in the ratio of 1.1:3.5:1.2:1.2. Following extraction for $12 \mathrm{~h}$, the extract was separated by filtration. The organic acids in the supernatant were aspirated into covered vials and determined by titration with $0.005 \mathrm{~N} \mathrm{NaOH}$ using $0.04 \%$ aqueous bromothymol blue as an indicator which became green at $\mathrm{pH}$. Total soluble sugars extracted by Ethanol and then determined by phenol-sulphoric acid methods as described by Sadasivam and Manickam, (1996)

Statistical analysis: The data were analyzed following Analysis of Variance (ANOVA) technique and mean separations were adjusted by the Multiple Comparison test (Norman and Streiner, 2003) using the statistical computer programme MSTAT-C v.1.2. Means were compared by using LSD test at $5 \%$ level of significance.

\section{RESULTS AND DISCUSSION}

\section{A: Organic solutes accumulation}

Significant differences were observed among the salt treatments for total free amino acids (TAA), proline (Pro), and glycinebetaine (GlyBet), total soluble sugars (TSC), and Total water soluble organic acids (TWSOA) accumulation under salinity levels up to $11.5 \mathrm{dSm}^{-1}$ in the soil. Data presented in Tables $(1,2)$ indicate that, wheat plants under salt-stressed conditions responded to an increased ion influx in their cells by increasing the synthesis and accumulation of flag leaf organic solutes i.e TAA, Pro, GlyBet, TSC and TWSOA in comparison with the control (Tables 1,2), which further increased with applications of either AsA or Toc under normal or salinity conditions and helped in maintaining the osmotic balance and thus helped in enhanced salt tolerance. The maximum concentration of organic solutes was recorded with the application of AsA and Toc combined with high salinity levels in comparison with antioxidants alone. AsA was more effective than Toc in this concern.

It is well known from the present investigation that the organic osmolytes were enhanced in response to $\mathrm{NaCl}$ and/or antioxidant treatments, where their interactions had an additive effect. Moreover, the toxic effects generated by sodium chloride were completely overcome by the application of AsA or Toc. Higher osmolytes accumulation, especially proline seems to be related to salt tolerance in wheat not to be a consequence of tissue reaction to salt stress damage. Antioxidants especially AsA appears to confer greater osmoprotectant by the additive role with $\mathrm{NaCl}$ in osmolyte accumulation.

It is confirmed that AsA may minimize deleterious effect of salt on plant growth and adaptation of wheat based on the higher magnitude of total free amino acids, proline, GlyBet and soluble sugars accumulation (Tajdoost et al., 2007, Siddiqui et al., 2008, Kholova et al., 2009). Hence, it might be assumed that AsA improves the salt tolerance of wheat by protecting the protein turnover machinery against stress damage and up-regulating stress protective proteins. 
J. Agric. Sci. Mansoura Univ., 34 (11), November, 2009

$\mathrm{T} 1-2$

10669 
Gadalla, S. F.

It has been reported that free amino acids contribute to osmotic adjustment, but experimental results are inconsistent (Ford, 1984). Free amino acids increased due to salt stress in wheat flag leaf up to $11.5 \mathrm{dsm}^{-1}$. These results were confirmed by Farouk, (2005) and Younis et al., (2009). The accumulation of amino acids in stressed plant could be caused by 1) protein degradation (Yadav et al, 1999) for providing amino acids needed for synthesis of new proteins suited for growth or survival under the modified conditions, and 2) inhibition of protein synthesis. In contrast, the results of present investigation proved that application of antioxidants increased significantly total free amino acids. In this concern, Abd EL-Aziz et al (2006) indicate that application of AsA acid increased significantly the proline content of Khaya senegalensis plant grown under normal or salinized conditions.

Proline concentrations, of all the organic solutes analyzed, showed the highest relative increase in response to salt stress (Table, 1). Proline accumulation may contribute to osmotic adjustment at the cellular level (Tripathi et al., 2007), hence, these solutes play an important role in osmoregulation. A direct consequence of higher osmolytes concentration in tolerant cultivars of wheat is the maintenance of comparatively higher RWC (Misra and Dwivedi, 2004) and up-regulation of specific enzymes of proline metabolism (Misra and Gupta, 2005). The significance of proline accumulation in osmotic adjustment is still debated and varies according to the species. However, convincing evidence is still lacking as to whether accumulation of proline can provide any biochemical adaptation for plants during salt stress. Antioxidants are directly involved in the changes taking place in the plant under salt stress. Pro has multiple functions, such as osmotic pressure regulation, protection of membrane integrity, stabilization of enzymes/proteins, maintain appropriate NADP+/NADPH ratios and scavenger of free radicals (Tripathi et al., 2007, Kaymakanova and Stoeva, 2008, Misra and Saxena, 2009), a major source of energy and nitrogen during immediate post-stress metabolism and the accumulated proline apparently supplies energy for growth and survival thereby inducing salinity tolerance (Jain et al., 2001). Over-accumulation of proline under either salt stress or antioxidants application or their interactions, in plants, has been attributed to the strategies adapted by plants to cope up with stress conditions (Misra and Gupta, 2005, Alqurainy, 2007). The increased or decreased regulation of enzymes of proline metabolism in response to salt stress or antioxidants has been demonstrated in many species (Sudhakar et al., 1993; Misra and Saxena, 2009). Such increase in proline content under salt stress or antioxidant application may be correlated with the increased synthesis of $\Delta^{1}$ pyrroline carboxylate synthetase (P5CS) and P5CS mRNA levels (Hare and Cress, 1996) and Pyrroline 5 carboxylate reductase (P5CR) (Misra and Gupta, 2006), and y-glutamyl kinase activity (Misra and Saxena 2009) or the low activity of degrading enzyme, proline oxidase (EC 1.5.99.8), localized in the inner mitochondrial membrane (Misra and Saxena 2009) and cytoplasmic proline dehydrogenase (EC 1.5.1.2) (Delauny and Verma,1993) to negligible rate. But till date, proline metabolism in presence of antioxidants is not known. Moreover, it is well known that increasing of total soluble sugars (Table, 2) may be correlated to proline accumulation. Many authors indicate 
that, the importance of soluble carbohydrates in stimulating of proline accumulation through an inhibition of the degradation enzymes of proline (Heineke et.al., 1992) meanwhile stimulated the synthesis enzymes of praline. In this concern Hare and Cress (1996) find that mRNA transcript encoding P5CR was increased in phloem tissue in response to water deprivation. This dramatic increase in transcription of the gene may be related to finding that when phloem loading of sucrose in blocked in potato, proline accumulation to very high level (Heineke et.al., 1992).

Glycinebetaine (GlyBet), a quaternary ammonium compound, is regarded as one of the most effective osmoprotectants owing to its many advantages besides its efficacy as a compatible solute. The molecular features of GlyBet enable its interaction with both the hydrophobic and hydrophilic domains of macromolecules without perturbing the cellular functions (Sakamoto and Murata 2002). It has been reported that GlyBet protects the cells from stresses by maintaining an osmotic balance between the intracellular and extracellular environments and by stabilizing the quaternary structures of complex proteins like antioxidants enzymes and biomembranes and other functional units like oxygen-evolving photosystem II complex (Rhodes and Hanson 1993). In the present study, it has been noticed that GlyBet over-accumulated contributes to the maintenance of OA in antioxidants treated plants under normal or salinized conditions. Some researchers have also reported that GlyBet induced the accumulation of osmolytes, such as soluble sugars, and free proline (Ma et al., 2004). Treatment of wheat plants with AsA or Toc increased significantly GlyBet level in flag leaf. Such an increase may be attributed to the fact that the addition of AsA promotes betaine formation by stimulating its biosynthesis. In this concern, Alqurainy (2007) revealed that application of AsA acid increased significantly GlyBet content in bean and pea seedlings grown under salinity stress.

Among the organic solutes, soluble carbohydrates contributed the most to the leaf osmotic potential, and they also seemed to be important in the leaf osmotic adjustment under salt stress conditions, as suggested by Greenway and Munns (1980), Tajdoost et al. (2007), and Kholova et al (2009). The increment in soluble carbohydrates due to salinity or antioxidants application may in turn play an important role in increasing the osmotic pressure of the cytoplasm. This conclusion is in accordance with the results obtained by Greenway and Munns (1980) who stated that these organic molecules act as osmotica and play an important role in osmotic adjustment in non-halophytes, moreover, sugars as osmolytes enable plants to keep better water relation under salt stress conditions. A strong correlation between sugar accumulation and osmotic tolerance has been widely reported (Bartels and Sunkar, 2005). The current hypothesis is that sugars act as osmotica and/or protect specific macromolecules and contribute to the stabilization of membrane structure. The accumulation of sugars was the result of an enhanced efficiency in the use of carbon coupled to a reduction in cellular metabolism, that could favor the accumulation of respiratory substrate to support the osmotic adjustment required to survive in saline media 
Gadalla, S. F.

(Schnapp et.al., 1990), this accumulation has been attributed to an impaired carbohydrates utilization (Munns and Termaat, 1986), and reduced respiration rate at high salinity level.

The measurement of increases in organic acids produced by mitochondria and cytosol can give information about respiratory activities and the equilibration of any cation excess, since catalytic mechanisms of hydrolysis of insoluble reserves are the first reactive to be activated by the passive absorption of water. Very little has been reported about the role of organic acids in plants due to salinity stress or antioxidant application. Former studies revealed increase in organic acid levels (citrate, malat... all linked to oxdation) in response to salinity addition (Bourgeais-Chaillou and Guerrier, 1992). High organic acid accumulations, positively related to salt-tolerance, were interpreted as an osmotic response to high salinity concentration in cotton (Timpa et.al., 1986) and tomato (Bourgeais-Chaillou and Guerrier, 1992). Organic acid have a role as osmotica as was previously described for Phaseolus vulgaris after exposure to sodium chloride shock under short-term experimental conditions (Ortiz et.al., 1994). The role of antioxidants on increasing the accumulation of organic acid under normal or salinized conditions needs further work to explain the actual role of antioxidants on organic acid accumulation in plant cell.

\section{B: Leaf water relations parameters:}

Water status is highly sensitive to salinity and is, therefore, dominant in determining the plant responses to stress. Progressively increasing salt stress up to $11.5 \mathrm{dSm}^{-1}$, affected all water relations parameters (Tables 3, 4). Both water potential, $\left(\Psi_{\mathrm{w}}\right)$ and osmotic potential, $\left(\boldsymbol{\Psi}_{\mathrm{s}}\right)$, drastically decreased (became more negative) due to increasing salt stress compared with the control plans, therefore, the values were the lowest at high salinity level. Likewise, water content, (WC), and relative water content, (RWC), dropped significantly with increasing salinity levels. The decreases were more pronounced in high salinity level. Osmotic adjustment (OA) capacity and leaf turgor potential, $\left(\Psi_{\mathrm{p}}\right)$ of wheat flag leaf increased significantly with decreasing $\psi_{\mathrm{w}}$ regardless of stress levels up to $11.5 \mathrm{dSm}^{-1}$ (Tables 3,4 ).

Either AsA or Toc foliar spray increased (less negative values) leaf water potential, water content and relative water content in flag leaf as compared with unsprayed plants, meanwhile decreased osmotic potential in flag leaf. Osmotic adjustment increased significantly in flag leaf with application of both antioxidants due to maintaining turgor potential of flag leaf. AsA was more effective than Toc in increasing leaf turgor under normal and saline conditions. However, the magnitude of $O A$ increased as the water deficit intensified as a result of decreasing $\Psi_{\mathrm{w}}$.

As regard to the interactions between antioxidants and salinity levels, the date in the same Tables proved that application of antioxidants, in particular, AsA under normal or salinized condition improved flag leaf water status due to decreasing leaf water potential, osmotic potential, and improving osmotic adjustment, and maintaining turgor potential. 
J. Agric. Sci. Mansoura Univ., 34 (11), November, 2009

T3-4

10673 
Gadalla, S. F.

It is noted that application of both antioxidants, in particular, AsA increased significantly relative water content under control or low salinity level, and then decreased under high salinity level. On the other hand water, application of both antioxidants, nullifies the harmful effect of salinity on water content.

Salinity stress is the major factor limiting plant growth and plant productivity (Farouk, 2005). The nature of salinity stress was of great importance in the water relations of the wheat plant treated with antioxidants compared with the untreated plant under normal or salinized conditions. These different responses could be due to the fact that wheat treated with antioxidants has some tolerance-avoiding mechanisms, such as osmotic adjustment $(\mathrm{OA})$, decrease in leaf water potential and decrease in leaf osmotic potential, to maintain their water status at values similar to those of the control plant (Tables 3,4). OA is a mechanism in plants to tolerate or avoiding salinity stress, by lowering the OP due to accumulation of compatible solutes, and to maintain the volume of protoplast and turgor pressure and increased rigidity of cell wall (Ludlow and Mu-Chow 1990). OA is a function of either an increase in the net osmoticum deposition rate in tissues and/or reduction in the rate of tissue volume expansion. The former is more likely to represent an adaptive response that could contribute to growth maintenance (Sharp et al., 2004). Leaf OA under salt stress was accomplished primarily by accumulation of some ions like $\mathrm{Na}^{+}, \mathrm{K}^{+}$and $\mathrm{Cl}^{-}$ (unpublished results). The OA in plants under saline stress, which occurs through salt accumulation, is less demanding in terms of energy and carbon use than adjustment involving organic solutes. However, this mechanism of leaf turgor maintenance by $\mathrm{Cl}^{-}$accumulation could also have negative effects in plants as leaf death (Silva et al., 2003). Upon exposure to salinity stress, many plants accumulate organic compatible solutes that are non-toxic at high concentrations; compatible solutes are defined as water-soluble organic compounds of a low molecular weight (termed also as osmoprotectants) (Chen and Murata 2002). It is generally accepted that the increase in cellular osmolarity which results from the accumulation compatible solutes is accompanied by the influx of water into, or at least a reduced efflux from, cells, thus providing the turgor necessary for cell expansion. Water potential, osmotic potential and turgor potential are inter-related in plant cells and are markedly affected when plants are exposed to salt stress. Although accumulation of organic solutes increased in both non-stressed and stressed plants due to foliar applied antioxidants (Tables 1,2), leaf osmotic potential was not greatly changed due to accumulation of organic solutes. From these finding, it is plausible to propose that changes in organic solutes accumulation caused slight change in leaf osmotic potential which resulted in improved leaf turgor potential and thus contribute in osmoregulatory processes. In the present investigation, foliar application of antioxidants, in particular, AsA, improved leaf water potential and leaf turgor potential, whereas leaf osmotic potential slightly decreased in the stressed plants due to its role in increasing compatible organic solutes and potassium (Tables $1,2)$.

The osmotic adjustment (OA) involves the net accumulation of organic solutes/osmolytes; total soluble sugars, total free amino acids, 
proline, and glycinebetaine (Munns 2005, Bandeh-hagh et al., 2008) in cells in response to a fall in the water potential of their environment. As a consequence of this net accumulation, the cell osmotic potential is lowered, and turgor pressure tends to be maintained (Blum et al., 1996). In the present investigation, salinity treatments markedly reduced the leaf water potential and this change was not compensated for by a reduction in leaf osmotic potential (Table, 3), the values of which showed only a small decrease compared to control plants, thus, turgor was not maintained and OA was not sufficient to offset the reduction in leaf water potential in salt-stressed plants. In glycophytes, the concentrations of compatible solutes that accumulate are not so high, on order of $10 \mathrm{mM}$, but if partitioned exclusively to the cytoplasm, they could generate a significant osmotic pressure and functions as an osmolytes. At low concentrations, these solutes presumably have another role, perhaps in stabilizing the tertiary structure of proteins, and function as osmoprotectants (Chen and Murata 2002). Compatible solutes synthesis comes with energy cost and hence involved a potential growth penalty. In leaf cell, approximately seven moles of ATP are needed to accumulate one mole of $\mathrm{NaCl}$ as an osmoticum, whereas the amount of ATP required to synthesis one mole of an organic compatible solute is an order of magnitude higher (Raven 1985). The ATP requirement for the synthesis or accumulation of solutes has been estimated as 3.5 for $\mathrm{Na}$, 34 for mannitol, 41 for proline, 50 for GlyBet, and approximately 52 for sucrose (Raven 1985). The synthesis of these compounds occurs at the expense of plant growth, but may allow the plant to survive and recover from the presence of high external concentrations of salt.

\section{C: Flag leaf structure:}

Leaf anatomical characters, such as thickness of upper epidermis (UE), thickness of lower epidermis (LE), thickness of big motor cell (BMC), thickness of leaf through midrib (TL), tangential dimension of midrib vascular bundle (TDMVB), tangential dimension of big xylem vessel (TDBXV), and thickness of mesophyll tissue (MT) of flag leaf were studied. Cross section of wheat flag leaves showed that there were significant changes in leaf anatomical characteristics induced by both antioxidants application. Application of either AsA or Toc increased the thickness of wheat leaf blade respectively, due to the increase in the thickness of mesophyll tissue as well as thickness of both lower and upper epidermis cells. In addition, the thickness of leaf blade through midrib region was also increased respectively, due to the increase in the midrib vascular bundle, as well as tangential and radial dimensions of big metaxylem vessel. Moreover, antioxidants increased the thickness of big motor cells. Antioxidants resulted in increasing the area of xylem and phloem tissues, due to the stimulation of pro-cambium activity in the midrib bundle during their differentiation. Ascorbic acid was more effective in increasing the thickness of the blade, dimension of xylem and phloem as well as the thickness of the mesophyll tissue (Table, 5).

Regarding the effect of salinity on flag leaf structure, the thicknesses of wheat flag leaf blade through the midrib region as well as the mesophyll tissue thickness were decreased under salinity levels. In addition, the tangential and 
Gadalla, S. F.

dimension of midrib vascular bundle and big metaxylem vessels, and thickness of xylem and phloem were also decreased. The decrease in mesophyll tissue, xylem and phloem leads to a slow rate on the translocation of photoassimilates towards the developing grains through the peduncle and spike rachilla. Furthermore, the decrease in the diameter of metaxylem vessels in the leaf blade results in lowering the accumulation of necessary water required for photosynthesis (Table, 5). Concerning the interaction between salinity and antioxidants, the interactions increased the wheat flag leaf blade thickness grown under high salinity level. On the other hand, antioxidants used partially overcome the depression effect of high salinity levels on the thickness of the midrib region and mesophyll tissue. Ascorbic was more effective than tocopherol in this concern.
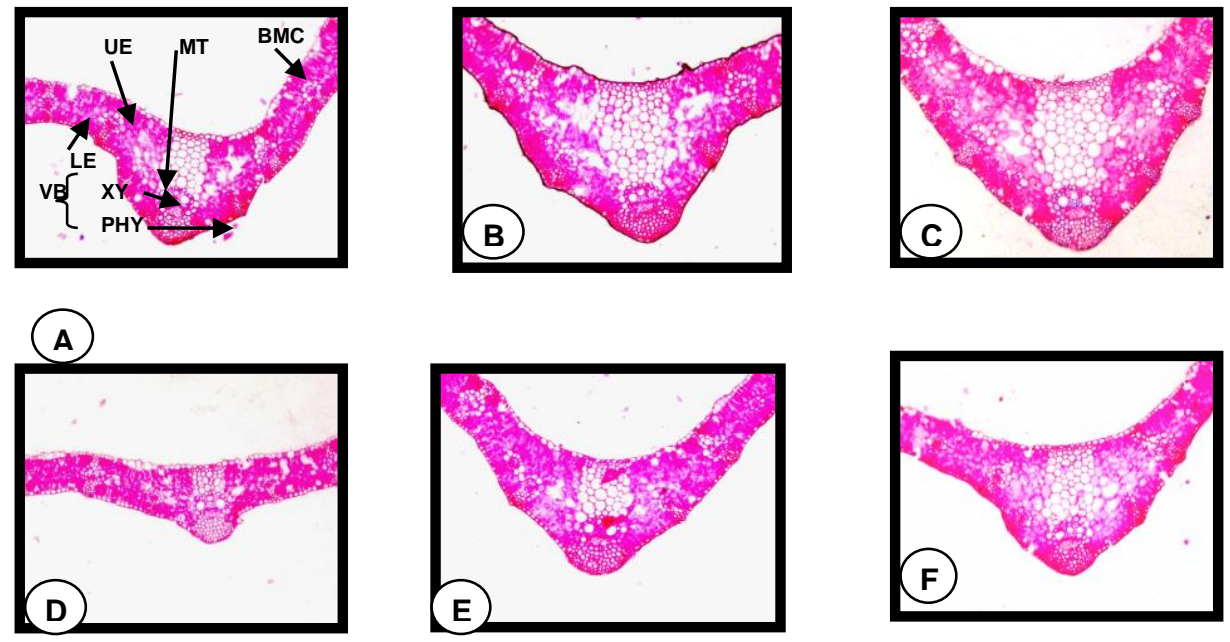

Figure (1) Leaf anatomical characteristics of flag leaf of wheat plants 65 DAS as affected by salinity or antioxidants as well as their combinations. ( $A=$ control, $B=T o c$ under control, $C=A s A$ under control, $D=$ high salinity level $11.5 \mathrm{dSm}-1, E=$ Toc under high salinity level, $F=$ AsA under high salinity level)

\section{D: Flag Leaf area and grain yield per plant:}

Restriction of leaf growth is among the earliest visible effects if many stress conditions, including salinity. Because leaves determine radiation interception and are the main photosynthetic organs, salinity stress effects on leaf expansion and functions are directly related to yield constraints under saline conditions. It is evident from results presented in Table (6), that increasing $\mathrm{NaCl}$ in rooting medium up to $11.5 \mathrm{ds} / \mathrm{m}$ had a significant adverse effect on flag leaf area and grain yield per plants. The great reduction in these parameters was observed under high salinity level. 
J. Agric. Sci. Mansoura Univ., 34 (11), November, 2009

T5-6

10677 
Gadalla, S. F.

It was noted that application of either AsA or Toc under normal or salinized conditions distinctly increase flag leaf area and grain yield per plant as compared with control plants or untreated plants under such salinity levels. The highest values of both parameters were recorded due to application of ASA. In general, AsA was more effective than Toc in this concern.

It is well known from the result of the present investigation that flag leaf area was progressively decreased with the increase of salinity (Table, 6). Similar results were reported by Farouk (2005), Shahbaz and Ashraf (2007). The decreased rate of leaf growth after an increase in soil salinity is primary due to reduction in water potential in the root zone is transmitted via the xylem to the leaves, causing leaf cells to loss water and reduced its elongation rates (Fricke and Peters 2002). Over days, reduction in cell elongation and also cell division lead to smaller final size. It is well known that cell expansion is dependent on water uptake, which relies on water potential gradients between the expanding cells and the water source. The relationship between solute uptake and leaf elongation under salinity has been examined in various systems. Soluble sugars (Kholova et al., 2009) and other organic solutes such as proline (de Luca et al, 2001, Misra and Saxena 2009) accumulate in the leaves under saline conditions and contribute to osmotic adjustment. They also help to sustain cell wall synthesis. Carbohydrates concentrations increase even when photosynthesis decreases in the expanded leaf (de Luca et al, 2001), and Carbon deposition is apparently mobilized by the demands of the expanding cells (Schnyder and Nelson, 1988). The actual relationship between turgor and leaf growth is complex. In agreement with more recent ideas about the mechanism of cell wall extensibility, cell enlargement beings with a reduction or relaxation of wall stress. As a consequence, turgor pressure and water potential are reduced, and water is drawn into the cell. The result is that the cell enlarges by uptake of water, initiated by a yielding of the wall. Synthesis and deposition of new wall materials is needed during or after cell enlargement to prevent wall rupture in subsequent growth. Cell wall elasticity is known to be closely related to cell size (Steudle et al., 1977). Bulk modulus of elasticity increased with cell size and thus small cells can withstand negative turgor pressure better than large cells. This was evident in our results, where the thickness of the mesophyll tissue, epidermis cell and vascular bundles decreased in the stressed plants indicating a reduction in cell size (table 5, Figure 1) due to inhibition of the pro-cambial activity from, primary vascular tissues as well as with a decrease in the number and size of mesophyll tissue. The reduction in cell size under salt stress conditions may be considered as salinity adaptation mechanisms (Steudle, 1997). On contrast, application of both antioxidants, in particular ASA, increased significantly flag leaf area under control or salinized conditions (Table, 6) due to hyper-accumulation of compatible solutes (Tables 1,2$)$ and potassium, and/or decreasing both sodium and chloride in flag leaf (unpublished results). Such accumulation provides the turgor necessary for cell expansion resulting in increasing leaf area (Munns and Termaat, 1986). This conclusion was supported by our results which indicate that application of both antioxidants increased leaf water potential and leaf osmotic potential as well as leaf turgor potential which resulted in increasing 
water uptake to cells and increasing relative water contents, resulted in increasing leaf cell elongation and flag leaf area. In addition, application of antioxidants increased total soluble sugars which serve as a substrate for increasing initiation of leaf primordial and decreasing plastochron duration (Munns et.al., 1979) which leads to increasing leaf area. This result was supported by several studies which confirmed that application of antioxidants increased significantly leaf area (Abd EL-Aziz et al., 2007). This was evident in our results, where the thickness of the mesophyll increased in plant treated with antioxidants under normal or salinized conditions indicating an increase in cell size (table 5, Figure 1).

Osmotic adjustment has received increasing interest during recent years. Associations between $O A$ and grain yield under water deficit in wheat (Moustafa et al., 1996), and sorghum (Santamaria et al., 1990) have been reported. However, the utility of OA as a mechanism of salinity tolerance is open to debate. Such a favorable effect of OA on yield and its components could presumably by attributed to the well-established role of $O A$ in maintaining turgor and plant growth under water deficit as observed in various crops (Morgan 1995, Grammatikopoulos 1999). Recently, Subbarao et al. (2000b) have recorded a significant positive relationship between OA and RWC under water deficit that lead to a significantly positive association between $O A$ and leaf area, indicating maintenance of crop growth by $O A$ under stress condition. That is, genotypes that adjusted osmotically, could maintain high photosynthetic rate because of more favorable leaf water status, which could, in turn, lead to higher crop growth rate and dry matter production, maintaining, ultimately, a higher productivity under salt stress. Thus, it could be inferred that maintenance of higher RWC at high salinity level in this study (Table, 4) could maintain growth and metabolic activities in plants, including, photosynthesis and other physiological processes (Subbarao et al., 2000b). Additionally, antioxidants treated plants could, presumably, translocate the pre-anathesis carbohydrates reserves to developing grains more efficiently than untreated plants. Moreover, OA could play a role in maintenance of turgor and better water content of leaves, which might help the plant, under salinity stress, to survive and maintain growth and metabolic activities so as to result, ultimately, in improved crop productivity. Finally, OA could play a role in maintenance of turgor and better water content of leaves, which might help the plant, under salinity stress, to survive and maintain growth and metabolic activities so as to result, ultimately, in improved crop productivity.

\section{ACKNOWLEDGEMENT}

I am grateful to all staff member of Agric. Botany Department, Fac. of Agriculture, Mansoura University. 


\section{REFERENCES}

Abd EL-Aziz Nahed G, E.M. EL-Quesni Fatma, and M.M. Farahat (2007). Response of vegetative growth and some chemical constituents of Syngonium podophyllum $\mathrm{L}$. to foliar application of thiamin, ascorbic acid and kinetin at Nubaria. World J. Agric. Sci. 3(3):301-305.

Abd ELAziz Nahed G, A.M. Mazher Azza, and E. EL-Habba (2006). Effect of foliar spraying with ascorbic acid on growth and chemical constituents of Khaya senegalensis grown under salt condition. American-Eurasian J. Agric . and Environ. Sci 1(3)207-214.

Alqurainy $F$ (2007). Responses of bean and pea to vitamin C under salinity stress. Research Journal of Agriculture and Biological Sciences 3(6):714-722.

Bandeh-Hagh A, M. Toorchi, A. Mohammadi, N. Chaparzadeh, G.H Salekdeh and H. Kazemnia (2008). Growth and osmotic adjustment of canola genotypes in response to salinity. J. Food, Agriculture and Environment 6(2) 201-208.

Bartels D, and R. Sunkar (2005). Drought and salt tolerance in plants. CRC Crit. Rev. Plant Sci. 24:23-58.

Barth C.M., De Tullio and P.L. Conklin (2006). The role of ascorbic acid in the control of flowering time and the onset of senescence. J. Exp. Bot. 57:1657-1665.

Beltagi MS (2008). Exogenous ascorbic acid (vitamin C) induced anabolic changes for salt tolerance in chickpea (Cicer arietinum L.) plants. African J. Plant Science 2(10): 118-123.

Blum A, J. Zhang and H.T. Nguyen (1999). Consistent differences among wheat cultivars in osmotic adjustment and their relationship to plant production. Field Crop Res. 64:287-291.

Blum A., R. Munns, J.B. Passioura, and N.C. Turner (1996). Genetically engineered plants resistant to soil dry and salt stress: How to interpret osmotic relations? Plant Physiol. 110:1050-1053.

Bohnert H.J. and R.G. Jensen (1996). Strategies for engineering water stress tolerance in plants. Trends Biotechnol. 14:89-97.

Bourgeais-Chaillou P. and G. Gurrier (1992): Salt-responses in Lycopersicon esculentum calli and whole plants. J. Plant physiol. 140:494-501.

Bray P.R.S., M. Bailey-Serres, and E. Weretilnyk (2000). Responses to a biotic stresses. In: Buchanan BB, Gruissen W, Jones RL (Eds.). Biochemistry and molecular biology of plants. ASPP, Rockville, pp. 1158-1203.

Chen T.H.H. and N. Murata (2002). Enhancement of tolerance of abiotic stress by metabolic engineering of betains and other compatible solutes. Curr. Opin. Plant Biol. 5:250-257.

Delauney A.J. and D.P.S. Verma (1993). Proline biosynthesis and osmoregulation in plants. Plant J. 4:215-223.

De Luca M, S. Garcia, K. Grunberg, Salgado, A. Cordoba, and C. Luna (2001). Physiological causes for decreased productivity under salinity in Boma, a tetrapolide Chloris gayana cultivar. Aust. J. Agric. Res. 52:903-910.

Dubey R.S. and M. Rani (1989a). Influence of $\mathrm{NaCl}$ salinity on growth and metabolic status of protein and amino acids in rice seedlings. J. Agron. Crop Sci. 162:97-106.

Dubey R.S., and M. Rani (1989b). Salinity induced accumulation of free amino acids in germinating rice seeds differing in salt tolerance. J. Agron. Crop Sci. 163:236-247. 
Farouk S. (2005). Response of Pisum sativum L. to some osmoregulators and plant growth substances under salt stress Ph.D Thesis, Faculty of Agriculture, Mansoura University, Egypt.

Fernandez-Ballester G., V. Martinez, D. Ruiz and A. Cerda (1998). Changes in inorganic and organic solutes in Citrus growing under saline stresses. J. Plant Nutrition 21(12):2497-2514.

Ford C.W. (1984). Accumulation of low molecular weight solutes in water stress tropical legumes. Phytochem. 23:1007-1015.

Foyer C.H. (1993). Ascorbic acid. In: Alscher R.G. and J.I. Hess (eds) Antioxidants in higher plants. Pp 31-58. CRC Press, Inc. Florida.

Fricke W., and W.S. Peters (2002). The biophysics of leaf growth in saltstressed barley: A study at the cell level. Plant Physiol. 129:374-388.

Gardner F.P., R.B. Pearce and R.L. Michell (1985). Physiology of crop plant. lowa State Univ. Press Ames. lowa. USA pp. 58-75.

Gossev N.A. (1960). Some methods in studying plant water relations. Leningrad Acad. Of Science. USSR.

Grammatikopoulos G. (1999). Mechanism of drought tolerance in two Mediterranean seasonal dimorphic shrubs. Aust. J. Plant Physiol. 26:587-593.

Greenway H. and R. Munns (1980). Mechanisms of salt tolerance in nonhalophytes. Annual Review of Plant Physiology 31:149-190.

Greive C.M. and S.R. Grattan (1983). Rapid assay for determination of water soluble quaternary amino compounds. Plant Soil 70:303-307

Hare P.D. and W.A. Cress (1996). Tissue-specific accumulation of transcript encoding- pyrroline-5- carboxylate reductase in Arabidopsis thalians. Plant Growth Regulation 19:249-256.

Hasegawa P.M., R.A. Bressan, J.K. Zhu and H.J. Bohnert (2000). Plant cellelular and molecular responses to high salinity. Annul. Rev. Plant Physiol. Plant Mol. Biol. 51:463-499.

Heineke D., U. Sonnewald, D. Bussis, G. Gunter, K. Leidreiter, I. Wilke, K. Rashke, L. Willmitzer and H.W. Heldt (1992). Apoplastic expression of yeast-derived invertase in potato. Plant Physiology 100:301-308.

Huang J. and R.E. Redmann (1995): Solute adjustment to salinity and calcium supply in cultivated and wild barley. J. Plant Nutrition 18(7): 1371-1389.

Hussein M.M., L.K. Balbaa and M.S. Gadallah (2007). Developing a salt tolerant cowpea using alpha tocopherol. J. Applied Sciences Research 3(10)1234-1239.

Jahnke L.S., and A.L. White (2003). Long-term hypothsaline and hyepcsaline stress produceistinct antioxidant responses in the marine algae Dunaliella teriolecta. J. Plant Physiol 160(10): 1193-1202.

Jain M., G. Mathur, S. Koul and N.B. Sarin (2001). Ameliorating effects of proline on salt stress lipid peroxidation in cell lines of groundnut (Archis hypogea L.). Plant Cell Report 20:463-468.

Kaymakanova M. and N. Stoeva (2008). Physiological reactions of bean plants (Phaseolus vulg. L.) to salt stress. Gen. Appl. Plant Physiol. 34(3-4) 177-188.

Kholova J., R.K. Sairam, R.C. Meena and G.C. Srivastava (2009). Response of maize genotypes to salinity stress in relation to osmolytes and metal ions contents, oxidative stress and antioxidant enzymes activity. Biol. Plant. 53(2) 249-256. 
Gadalla, S. F.

Kiani S.P., P. Talia, P. Maury, P. Grieu, R. Heinz, A. Perrault, V. Nishinakamusu, E. Hopp, L. Gentzbittel, N. Paniego and A. Sarrafi (2007). Genetic analysis of plant water status and osmotic adjustment in recombinant inbred lines of sunflower under two water treatments. Plant Sci. 172(4) 773-778.

Lacerda C.F., J. Cambraia, M.A.O. Cano, H.A. Ruiz, and J.T. Prisco (2003) Solutes accumulation and distribution during shoot and leaf development in two sorghum genotypes under salt stress. Environ. Exp. Bot. 49:107-120.

Leport L., N.C. Turner, R.J. French, M.D. Barr, R. Duda, S.L. Davies, D. Tennant and K.H.M. Siddique (1999). Physiological response of chickpea gentotypes to terminal drought in a Mediterranean type environment. Eur. J. Agron. 11:279-291.

Ludlow M.M., and R.C. Mu-Chow (1990). A critical evaluation of traits for improving crop yields in water-limited environments. Adv. Agro. 43:107152.

Magne C. and F. Larher (1992). High sugar content of extracts interfers with colorimetric determination of amino acids and free proline. Anal. Biochem. 200:358-362.

Ma Q.Q., Q. Zou, Y.H. Li, D.Q. Li, and W. Wang (2004). Amelioration of the water status and improvement of the anti-oxidant enzyme activities by exogenous glycinebetaine in water-stressed wheat seedlings. Acta Agron. Sinica 4:321-328.

Meloni D.A., M.A. Oliva, H.A. Ruiz and C.A. Martinez (2001). Contribution of proline and inorganic solutes to osmotic adjustment in cotton under salt stress. J. Plant Nutrition 24:599-612.

Misra N. and A.K. Gupta (2005). Effect of salt stress on on proline metabolism in two high yielding genotypes of green gram. Plant Sci. 169:331-339.

Misra N. and A.K. Gupta (2006). Interactive effects of sodium and calcium on proline metabolism in salt tolerant green gram cultivar. American J. Plant Physiol. 1(1)1-12.

Misra N. and P. Saxena (2009). Effect of salicylic acid on proline metabolism in lentil grown under salinity stress. Plant Sci. 177:181-189.

Misra N. and U.N. Dwivedi (2004). Genotypic difference in salinity tolerance of green gram cultivars. Plant Sci. 166:1135-1142.

Morgan J.M. (1995). Growth and yield of wheat lines with differing osmoregulative capacity at high soil water deficit in seasons of varying evaporative demand. Field Crop Research 40:143-152.

Moustafa M.A., L. Boersma, and W.E. Kronstad (1996). Response of four spring wheat cultivars to drought stress. Crop Sci. 36:982-986.

Munns M. (2002). Comparative physiology of salt and water stress. Plant Cell Environ 25:230-250.

Munns R. (1988). Why measure osmotic adjustment? Aust. J. Plant Physiol. $15: 717-726$

Munns R. (2005). Gene and salt tolerance: bringing them together. New Phytologist 167:645-663

Munns R. and A. Termaat (1986). Whole plant responses to salinity. Australian J. Plant Physiology 13:143-160.

Munns R., C.J. Brady and E.W.R. Barlow (1979): Solutes accumulation in the apex and leaves of wheat during water stress. Aust. J. Plant Physiol. 6:379-389.

Norman G.R. and D.L. Streiner (2003). PDQ Statistics, 3rd Ed. BC Deckker Inc, London. ISBN 1-55009-2073. 
Ortiz A., V. Martinez and A. Cerda (1994): Effects of osmotic shock and calcium on growth and solute composition of Phaseolus vulgaris plants. Physiologia Plantarum. 91:468-476.

Raven J.A. (1985). Regulation of $\mathrm{pH}$ and generation of osmolarity in vascular plants: a cost-benefit analysis in relation to efficiency of use of energy, nitrogen and water. New Phyto. 101:25-77.

Rhodes D. and A.D. Hanson (1993). Quaternary ammonium and tertiary sulfonium compounds in higher plants. Annu. Rev. Plant Physiol. Plant Mol. Biol. 44:357-384.

Rontein D., G. Basset, and A.D. Hanson (2002). Metabolic engineering of osmoprotectants accumulation in plants. Metab. Engineer. 4:49-56.

Sadasivam S. and A. Manickam (1996). Biochemical methods, $2^{\text {nd }}$ Ed., New age international. India.

Sakamoto A. and N. Murata (2002). The role of glycine betaine in the protection of plants from stress: clues from transgenic plants. Plant Cell Environment 25:163-171.

Santamaria J.M., M.M. Ludlow, and S. Fukai (1990). Contribution of osmotic adjustment to grain yield in Shorgum bicolor L. Moench under water limited conditions. I. Water stress before anathesis. Aust. J. Agric. Res. 41:51-65.

Schnapp S.R., R.A. Bressan and P.M. Hasegawa (1990). Carbon used efficiency and cell expansion of $\mathrm{NaCl}$-adapted tobacco cells. Plant Physiology 93:384-388.

Schnyder H., and C.J. Nelson (1988). Diurnal growth of tall fescue leaf blades. I. Spatial distribution of growth, deposition of water, and assimilate import in the elongation zone. Plant Physiol. 86:1070-1076.

Serraj R. and T.R. Sinclair (2002). Osmolyte accumulation: can it really help increase crop yield under drought conditions? Plant Cell Environm. 25:333-341

Shahbaz M. and M. Ashraf (2007). Influence of exogenous application of brassinosteroid on growth and mineral nutrients of wheat (Triticum aestivum L.) under saline conditions. Pak. J. Bot. 39(2): 513-522.

Shalata A. and P.M. Neumann (2001). Exogenous ascorbic acid (vitamin C) increases resistance to salt stress and reduces lipid peroxidation. J. Experimental Botany 52(364): 2207-2211.

Sharp R.E., V. Poroyko, L.G. Hejlek, W.G. Spollen, G.K. Springer, H.J. Bohnert and H.T. Nguyen (2004). Root growth maintenance during water deficits: physiology to functional genomics. J. Exp. Bot. 55:23432351.

Siddiqui M.H., M.N. Khan, F. Mohammad and M.M.A. Khan (2008). role of nitrogen and gibberellin (GA3) in the regulation of enzyme activities and in osmoprotectant accumulation in Brassica juncea L. under salt stress. J. Agron. Crop Sci. 194:214-224.

Silva, J.V., C.F. de Lacerda, P.H. A. de Costa, J. E. Filho, E. G. Filho and J. $\mathrm{T}$. Prisco (2003). Physiological responses of $\mathrm{NaCl}$ stressed cowpea plants grown in nutrient solution supplemented with $\mathrm{CaCl}_{2}$. Braz. J. Plant Physiol. 15(2): 99-105.

Singh D.V., G.C. Srivastava and M.Z. Abding (2001). Amelioration of negative effect of water stress in Cassia angustifolia by benzyladenine and/or ascorbic acid. Biol. Plant 44:141-143.

Smirnoff N. (1996). The function and metabolism of ascorbic acid in plants. Ann. Bot. 78:661-669.

Sohan D., R. Jasoni and J. Zajicek (1999). Plant-Water relations of $\mathrm{NaCl}$ and Calcium-treated sunflower plants. Envir. and Exp. Botany 42: 105-111. 
Gadalla, S. F.

Steudle E. (1997). Water transport across plant tissue: role of water channels. Biol. Cell. 89:259-273.

Steudle E., U. Zimmermann, and U. Luttge (1977). Effect of turgor pressure and cell size on the wall elasticity of plant cells. Plant Physiology 59:285-289.

Subbarao G.V., N.H. Nam, Y.S. Chauhan and C. Johanson (2000b). Osmotic adjustment, water relations and carbohydrate remobilization in pigeonpea under water deficits. J. Plant Physiol. 157:651-659.

Subbarao G.V., Y.S. Chauhan and C. Johanson (2000a). Patterns of osmotic adjustment in pigeonpea -its importance as a mechanism of drought resistance. Eur. J. Agron. 12:239-249.

Sudhakar C., P.S. Reddy and K. Veeranjaneyulu (1993). Effects of salt stress on the enzymes of praline synthesis and oxidation of green gram seedlings. J. Plant Physiol. 141:621-623.

Taiz L. and E. Zeiger (1998). Plant Physiology, $2^{\text {nd }}$ Ed. Sinauer Associate, Inc, USA.

Tajdoost S., T. Farboodnia and R. Heidari (2007). Salt pretreatment enhance salt tolerance in Zea mays L. seedlings. Pak. J. Biol. Sciences 10 (12):2086-2090.

Talaat N.B. (2003). Physiological studies on the effect of salinity, ascorbic acid and putrescine of sweet pepper plant. Ph.D thesis, Fac. Agric., Cairo Univ.

Tangpremsri T., S. Fukai and K.S. Fischer (1995). Growth and yield of sorghum lines extracted from a population for differences in osmotic adjustment. Aust. J. Agric. Res. 46:61-74.

Timpa J.D., J.J. Burke, J.E. Quisemberry and C.W. Wendt (1986). Effects of water stress on the organic acid and carbohydrate compositions of cotton plants. Plant physiology 82:724-728.

Tripathi S.B., k. Gurumurthi, A.K. Panigrahi and B.P. Shaw (2007). Salinity induced changes in proline and betaine contents and synthesis in two aquatic macrophytes differing in salt tolerance. Biol. Plant 51:110-115.

Verslues P.E. and R.E. Sharp (1999). Praline accumulation in maize (Zea mays L.) primary roots at low water potential. II. Metabolic source of increased proline deposition in the elongation zone. Plant Physiology 119:1349-1360.

Westgate M.E. and J.S. Boyer (1985). Osmotic adjustment and the inhibition of leaf, root, stem, and silk growth at low water potentials in maize. Planta 164:540-549.

Yadav V.K., V. Gupta and Y. Neflam (1999). Hormonal regulation of nitrate in gram (Cicer arietinum) genotypes under drought. Indian J. Agric. Sci. 69:592-595.

Yeo A. (1998). Molecular biology of salt tolerance in the context of wholeplant physiology. J. Exp. Bot. 49:915-929.

Younis M.E., M.N.A. Haaneen, and A.M.S. Kazamel (2009). Plant growth, metabolism and adaptation in relation to stress conditions. XXVII. Can ascorbic acid modify the adverse effects of NACl and mannitol on amino acids, nucleic acids and protein patterns in Vicia faba seedlings?. Protoplasma 235:37-47. 
دور المواد المضادة للأكسدة فى تعديل الضبط الأسموزى لورقة العـم لتبـات القــح النامي تحث ظروف الإجهاد الملحي سعد فاروق جاد الله إنه قسم النبات الزراعى، كلية الزراعه، جامعه المنصورة

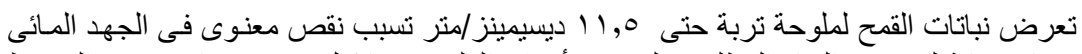

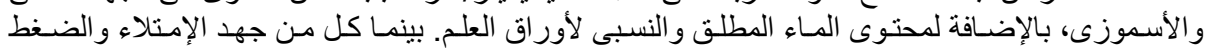

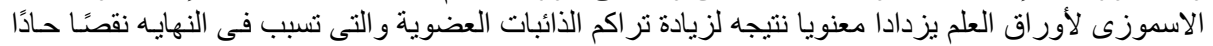

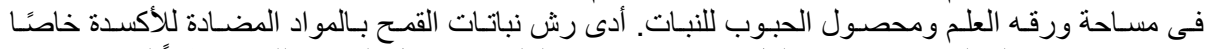

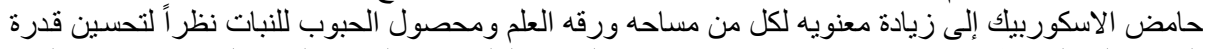

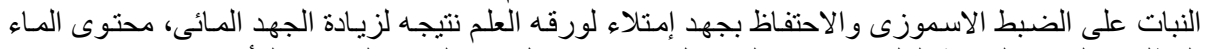

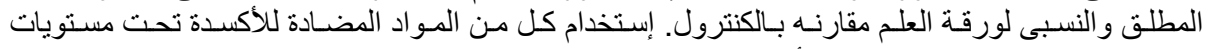

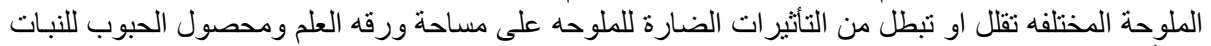

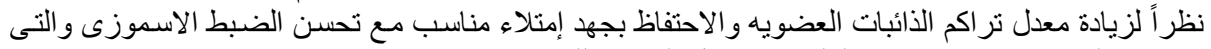

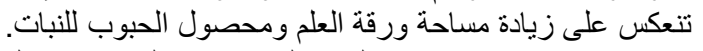

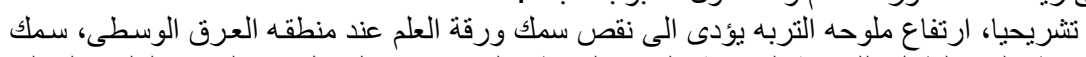

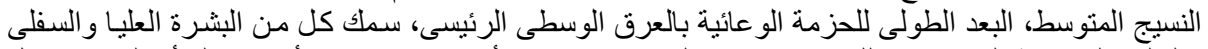

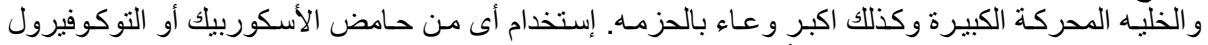

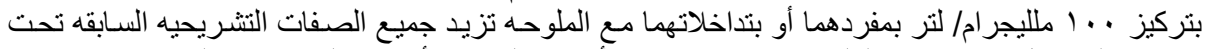

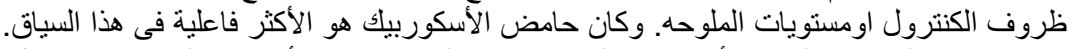

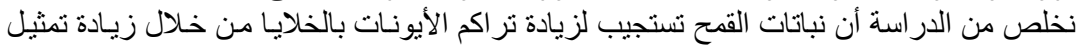

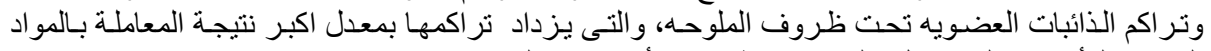

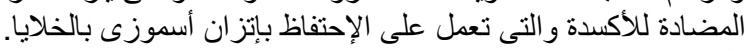

كلية الزراعه - جامعة المنصوره كلية الزراعه - جامعة الزراعه جامعة المنهوره

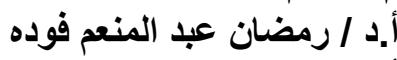
أ.د / محمود ابر اهيم حسن عن المن فوده 
Gadalla, S. F.

10686 
Table (1) Total free amino acids, Proline and Glycinebetaine ( $\mathrm{mg} / \mathrm{g} \mathrm{FW}$ ) of wheat flag leaf as affected by salinity or antioxidants as well as their combinations in the two growing season

\begin{tabular}{|c|c|c|c|c|c|c|c|c|c|c|c|c|}
\hline \multirow{3}{*}{\begin{tabular}{|l} 
Characters \\
Salinity \\
$\left(\mathrm{dSm}^{-1}\right)$
\end{tabular}} & \multicolumn{12}{|c|}{ Antioxidants (B) } \\
\hline & \multicolumn{4}{|c|}{ Total Free Amino Acids } & \multicolumn{4}{|c|}{ Proline } & \multicolumn{4}{|c|}{ Glycinebetaine } \\
\hline & 0 & AsA & $\alpha-T o c$ & $\begin{array}{l}\text { Mean of } \\
\text { salinity }\end{array}$ & 0 & AsA & $\alpha-T o c$ & $\begin{array}{c}\text { Mean } \\
\text { of } \\
\text { salinity }\end{array}$ & 0 & AsA & $\alpha-T o c$ & $\begin{array}{c}\text { Mean } \\
\text { of salinity }\end{array}$ \\
\hline \multicolumn{13}{|c|}{ First season } \\
\hline Control (0.12) & 79.83 & 89.41 & 87.48 & 85.57 & 9.97 & 15.63 & 15.02 & 13.54 & 1.053 & 1.753 & 1.253 & 1.353 \\
\hline 7.5 & 91.64 & 97.25 & 93.95 & 94.28 & 16.25 & 17.96 & 17.37 & 17.19 & 2.700 & 4.163 & 3.583 & 3.482 \\
\hline 11.5 & 104.0 & 115.7 & 99.68 & 106.4 & 19.45 & 21.87 & 20.06 & 20.46 & 4.663 & 6.037 & 5.323 & 5.341 \\
\hline Mean of antioxidants & 91.82 & 100.8 & 93.70 & & 15.22 & 18.49 & 17.48 & & 2.806 & 3.984 & 3.387 & \\
\hline LSD 5\% & $\begin{array}{c}\text { A } \\
2.347\end{array}$ & $\begin{array}{c}B \\
2.34\end{array}$ & $\begin{array}{c}A B \\
4.06\end{array}$ & & $\begin{array}{c}A \\
0.715\end{array}$ & $\begin{array}{c}\mathrm{B} \\
0.712\end{array}$ & $\begin{array}{c}\mathrm{AB} \\
1.233\end{array}$ & & $\begin{array}{c}A \\
0.310\end{array}$ & $\begin{array}{c}B \\
0.310\end{array}$ & $\begin{array}{l}\mathrm{AB} \\
\mathrm{NS}\end{array}$ & \\
\hline \multicolumn{13}{|c|}{ Second season } \\
\hline Control (0.12) & 80.33 & 88.72 & 87.64 & 85.56 & 10.71 & 15.01 & 14.41 & 13.38 & 1.297 & 1.803 & 1.567 & 1.556 \\
\hline 7.5 & 90.38 & 96.01 & 94.19 & 93.53 & 16.16 & 17.55 & 17.34 & 17.02 & 2.423 & 3.793 & 3.550 & 3.256 \\
\hline 11.5 & 104.2 & 111.9 & 100.8 & 105.6 & 18.84 & 21.18 & 20.41 & 20.14 & 4.383 & 5.917 & 5.407 & 5.236 \\
\hline Mean of antioxidants & 91.64 & 98.88 & 94.23 & & 15.24 & 17.91 & 17.39 & & 2.701 & 3.838 & 3.508 & \\
\hline LSD $5 \%$ & $\begin{array}{c}A \\
A .546\end{array}$ & $\begin{array}{c}B \\
B \\
1.54\end{array}$ & $\begin{array}{c}A B \\
2.675\end{array}$ & & $\begin{array}{c}A \\
0.562\end{array}$ & $\begin{array}{c}B \\
0.564\end{array}$ & $\begin{array}{c}A B \\
0.977\end{array}$ & & $\begin{array}{c}A \\
0.177\end{array}$ & $\begin{array}{c}B \\
0.176\end{array}$ & $\begin{array}{c}A B \\
0.305\end{array}$ & \\
\hline
\end{tabular}

Table (2) Total soluble sugars and Total water soluble organic acids of wheat flag leaf as affected by salinity or antioxidants as well as their combinations in two growing season

\begin{tabular}{|c|c|c|c|c|c|c|c|c|}
\hline \multirow{3}{*}{$\begin{array}{l}\text { Characters } \\
\text { Salinity } \\
\left(\mathrm{dSm}^{-1}\right) \\
\end{array}$} & \multicolumn{8}{|c|}{ Antioxidants (B) } \\
\hline & \multicolumn{4}{|c|}{ Total Soluble Sugars } & \multicolumn{4}{|c|}{ Total Water Soluble Organic Acids } \\
\hline & 0 & AsA & A-Toc & $\begin{array}{l}\text { Mean of } \\
\text { salinity }\end{array}$ & 0 & AsA & $\alpha-T o c$ & Mean of salinity \\
\hline \multicolumn{9}{|c|}{ First season } \\
\hline Control (0.12) & 15.490 & 23.247 & 20.597 & 19.778 & 32.30 & 46.00 & 40.567 & 39.622 \\
\hline 7.5 & 23.937 & 27.787 & 26.623 & 26.116 & 51.100 & 55.667 & 52.867 & 53.211 \\
\hline 11.5 & 28.027 & 35.700 & 31.123 & 31.617 & 58.433 & 67.467 & 62.600 & 62.833 \\
\hline Mean of antioxidants & 22.484 & 28.911 & 26.114 & & 47.178 & 56.378 & 52.011 & \\
\hline LSD 5\% & $\begin{array}{c}A \\
0.855\end{array}$ & $\begin{array}{c}\mathrm{B} \\
0.856\end{array}$ & $\begin{array}{c}A B \\
1.483\end{array}$ & & $\begin{array}{c}A \\
2.971\end{array}$ & $\begin{array}{c}B \\
2.974\end{array}$ & $\begin{array}{c}A B \\
5.151\end{array}$ & \\
\hline \multicolumn{9}{|l|}{ Second season } \\
\hline Control (0.12) & 15.700 & 23.227 & 20.407 & 19.778 & 32.800 & 44.167 & 42.200 & 39.722 \\
\hline 7.5 & 24.640 & 28.457 & 26.213 & 26.437 & 47.800 & 54.333 & 52.833 & 51.656 \\
\hline 11.5 & 27.747 & 34.333 & 31.447 & 31.176 & 56.733 & 65.633 & 63.767 & 62.044 \\
\hline Mean of antioxidants & 22.696 & 28.672 & 26.022 & & 45.778 & 54.711 & 52.933 & \\
\hline LSD 5\% & $\begin{array}{c}A \\
0.526 \\
\end{array}$ & $\begin{array}{c}B \\
0.527\end{array}$ & $\begin{array}{c}A B \\
0.914 \\
\end{array}$ & & $\begin{array}{c}A \\
1.965\end{array}$ & $\begin{array}{c}B \\
1.966 \\
\end{array}$ & $\begin{array}{l}\text { AB } \\
\text { NS }\end{array}$ & \\
\hline
\end{tabular}


Table (3) Leaf Water Potential, Leaf Osmotic Potential (-Mpa ) and Leaf Turgor Potential (Mpa) of wheat flag leaf as affected by salinity or antioxidants as well as their combinations in the two growing season

\begin{tabular}{|c|c|c|c|c|c|c|c|c|c|c|c|c|}
\hline \multirow{3}{*}{\begin{tabular}{|l} 
Characters \\
$\begin{array}{l}\text { Salinity } \\
\left(\mathrm{dSm}^{-1}\right)\end{array}$
\end{tabular}} & \multirow{2}{*}{\multicolumn{8}{|c|}{$\begin{array}{c}\text { Antioxidants (B) } \\
\text { Leaf Osmotic Potential }\end{array}$}} & \multirow{2}{*}{\multicolumn{4}{|c|}{ Leaf Turgor Potential }} \\
\hline & & & & & & & & & & & & \\
\hline & 0 & AsA & $\alpha$-Toc & $\begin{array}{l}\text { Mean of } \\
\text { salinity }\end{array}$ & 0 & AsA & $\alpha$-Toc & $\begin{array}{l}\text { Mean of } \\
\text { salinity }\end{array}$ & 0 & AsA & $\alpha$-Toc & $\begin{array}{c}\text { Mean of } \\
\text { salinity }\end{array}$ \\
\hline \multicolumn{13}{|c|}{ First season } \\
\hline Control (0.12) & -0.209 & -0.252 & -0.233 & -0.231 & -0.625 & -0.686 & -0.660 & -0.657 & 0.416 & 0.434 & 0.427 & 0.426 \\
\hline & -0.362 & -0.273 & -0.296 & -0.310 & -0.713 & -0.866 & -0.751 & -0.777 & 0.351 & 0.541 & 0.455 & 0.449 \\
\hline 11.5 & -0.383 & -0.313 & -0.341 & -0.346 & -0.824 & -0.937 & -0.906 & -0.889 & 0.422 & 0.624 & 0.565 & 0.544 \\
\hline Mean of antioxidants & -0.318 & -0.279 & -0.290 & & -0.721 & -0.830 & -0.772 & & 0.403 & 0.533 & 0.482 & \\
\hline LSD 5\% & $\begin{array}{c}A \\
0.0162\end{array}$ & $\begin{array}{c}B \\
0.0101\end{array}$ & $\begin{array}{c}\mathrm{AB} \\
0.020\end{array}$ & & $\begin{array}{c}A \\
0.0162\end{array}$ & $\begin{array}{c}\mathrm{B} \\
0.0195\end{array}$ & $\begin{array}{c}\mathrm{AB} \\
0.033\end{array}$ & & $\begin{array}{c}A \\
0.043\end{array}$ & $\begin{array}{c}\mathrm{B} \\
0.0407\end{array}$ & $\begin{array}{c}A B \\
0.0708\end{array}$ & \\
\hline \multicolumn{13}{|c|}{ ond season } \\
\hline Control (0.12) & -0.207 & -0.252 & -0.226 & -0.228 & -0.616 & -0.677 & -0.654 & -0.649 & 0.409 & 0.426 & 0.429 & 0.421 \\
\hline & -0.359 & -0.281 & -0.308 & -0.316 & -0.706 & -0.831 & -0.739 & -0.759 & 0.346 & 0.507 & 0.431 & 0.428 \\
\hline 11.5 & -0.380 & -0.324 & -0.347 & -0.350 & -0.901 & -0.944 & -0.924 & -0.923 & 0.521 & 0.621 & 0.577 & 0.573 \\
\hline Mean of antioxidants & -0.315 & -0.286 & -0.293 & & -0.741 & -0.817 & -0.772 & & 0.426 & 0.518 & 0.479 & \\
\hline LSD 5\% & $\begin{array}{c}A \\
0.010\end{array}$ & $\begin{array}{c}B \\
0.010\end{array}$ & $\begin{array}{l}A B \\
0.0179\end{array}$ & & $\begin{array}{c}A \\
0.0054\end{array}$ & $\begin{array}{c}\mathrm{B} \\
0.0093 \\
\end{array}$ & $\begin{array}{c}\mathrm{AB} \\
0.0162\end{array}$ & & $\begin{array}{c}A \\
0.0354\end{array}$ & $\begin{array}{c}B \\
0.0333\end{array}$ & $\begin{array}{l}\mathrm{AB} \\
0.058\end{array}$ & \\
\hline
\end{tabular}

Table (4) Water content, Relative Water Content percentage and Osmotic Adjustment (Mpa )of flag leaf of wheat plant as affected by salinity or antioxidants as well as their combinations in the two growing season

\begin{tabular}{|c|c|c|c|c|c|c|c|c|c|c|c|c|}
\hline \multirow{3}{*}{$\begin{array}{l}\text { Characters } \\
\begin{array}{l}\text { Salinity } \\
\left(\mathrm{dSm}^{-1}\right)\end{array}\end{array}$} & \multicolumn{12}{|c|}{ Antioxidants (B) } \\
\hline & \multicolumn{4}{|c|}{ Osmotic Adjustment } & \multicolumn{4}{|c|}{ Water Content } & \multicolumn{4}{|c|}{ Relative water Content } \\
\hline & 0 & AsA & $\alpha$-Toc & $\begin{array}{c}\text { Mean of } \\
\text { salinity }\end{array}$ & 0 & AsA & $\alpha-$ Toc & $\begin{array}{l}\text { Mean of } \\
\text { salinity }\end{array}$ & 0 & AsA & $\alpha-T o c$ & $\begin{array}{l}\text { Mean of } \\
\text { salinity }\end{array}$ \\
\hline \multicolumn{13}{|c|}{ First seaon } \\
\hline Control (0.12) & 0.00 & 0.124 & 0.098 & 0.074 & 86.36 & 89.13 & 87.11 & 87.53 & 77.30 & 92.95 & 90.83 & 87.03 \\
\hline 7.5 & 0.154 & 0.240 & 0.182 & 0.192 & 83.83 & 86.91 & 85.17 & 85.30 & 71.01 & 83.68 & 79.83 & 78.17 \\
\hline 11.5 & 0.211 & 0.292 & 0.266 & 0.256 & 72.72 & 83.09 & 84.07 & 79.96 & 60.47 & 77.32 & 72.47 & 70.08 \\
\hline Mean of antioxidants & \begin{tabular}{|l|}
0.122 \\
\end{tabular} & 0.218 & 0.182 & & 80.97 & 86.38 & 85.45 & & 69.59 & 84.65 & 81.04 & \\
\hline LSD 5\% & \begin{tabular}{|c|}
$A$ \\
0.0073
\end{tabular} & $\begin{array}{c}B \\
0.0069\end{array}$ & $\begin{array}{c}A B \\
0.0118\end{array}$ & & $\begin{array}{c}A \\
2.228\end{array}$ & $\begin{array}{c}B \\
2.16\end{array}$ & $\begin{array}{c}A B \\
3.80\end{array}$ & & $\begin{array}{c}A \\
0.74\end{array}$ & $\begin{array}{c}\mathrm{B} \\
0.713\end{array}$ & $\begin{array}{c}A B \\
1.307\end{array}$ & \\
\hline \multirow{2}{*}{\multicolumn{13}{|c|}{ ond season }} \\
\hline Control (0.12) & & & 0.128 & & 85.63 & 91.24 & 89.19 & 88.69 & 78.28 & 89.16 & 83.01 & 83.48 \\
\hline 7.5 & \begin{tabular}{|l|}
0.168 \\
\end{tabular} & 0.206 & 0.186 & 0.187 & 82.43 & 88.39 & 84.85 & 85.23 & 75.86 & 80.16 & 77.51 & 77.84 \\
\hline 11.5 & \begin{tabular}{|l|}
0.227 \\
\end{tabular} & 0.283 & 0.262 & 0.257 & 67.01 & 82.90 & 79.18 & 76.36 & 60.96 & 73.38 & 71.77 & 68.70 \\
\hline Mean of antioxidants & 0.132 & 0.213 & 0.192 & & 78.36 & 87.51 & 84.41 & & 71.70 & 80.90 & 77.43 & \\
\hline LSD 5\% & \begin{tabular}{|c|}
$A$ \\
0.024
\end{tabular} & $\begin{array}{c}B \\
0.0231\end{array}$ & $\begin{array}{c}A B \\
0.0398\end{array}$ & & $\begin{array}{c}A \\
0.95\end{array}$ & $\begin{array}{c}B \\
0.92\end{array}$ & $\begin{array}{c}A B \\
1.60\end{array}$ & & $\begin{array}{c}\text { A } \\
1.90\end{array}$ & $\begin{array}{c}B \\
1.87\end{array}$ & $\begin{array}{c}\mathrm{AB} \\
2.35\end{array}$ & \\
\hline
\end{tabular}


Table (5) Leaf anatomical characteristics $(\mu)$ of flag leaf of wheat plants at 65 DAS as affected by salinity or antioxidants as well as their combinations in the second season.

\begin{tabular}{|c|c|c|c|c|c|c|c|c|c|c|c|c|c|c|c|}
\hline \multicolumn{2}{|c|}{ Treatment } & \multicolumn{2}{|c|}{$\begin{array}{c}\text { Thickness of } \\
\text { upper epidermis } \\
\text { (UE) }\end{array}$} & \multicolumn{2}{|c|}{$\begin{array}{c}\text { Thickness of } \\
\text { lower epidermis } \\
\text { (LE) }\end{array}$} & \multicolumn{2}{|c|}{$\begin{array}{l}\text { Thickness of } \\
\text { big motor cell } \\
\text { (BMC) }\end{array}$} & \multicolumn{2}{|c|}{$\begin{array}{l}\text { Thickness of } \\
\text { leaf through } \\
\text { midrib (TL) }\end{array}$} & \multicolumn{2}{|c|}{\begin{tabular}{|c|} 
Tangential \\
dimension of \\
midrib vascular \\
bundle (TDMVB)
\end{tabular}} & \multicolumn{2}{|c|}{\begin{tabular}{|c|} 
Tangential \\
dimension of big \\
xylem vessel \\
(TDBXV)
\end{tabular}} & \multicolumn{2}{|c|}{$\begin{array}{l}\text { Thickness of } \\
\text { mesophyll tissue } \\
\text { (MT) }\end{array}$} \\
\hline $\begin{array}{l}\text { Salinity } \\
\left(\mathrm{dSm}^{-1}\right)\end{array}$ & Antioxid & & $\%$ & & $100 \%$ & & $100 \%$ & & $100 \%$ & & $100 \%$ & & $100 \%$ & & $100 \%$ \\
\hline \multirow{3}{*}{$\begin{array}{l}\text { Control } \\
(0.12)\end{array}$} & Water & 5.00 & 100 & 4.33 & 100 & 9.66 & 100 & 185.3 & 100 & 65.0 & 100 & 8.66 & 100 & 93.6 & 100 \\
\hline & AsA & 5.66 & 113.2 & 5.66 & 130.7 & 11 & 113.87 & 250.6 & 135.24 & 82.6 & 127.07 & 10 & 115.47 & 111.6 & 116.12 \\
\hline & Toc & 5.66 & 113 & 5 & 115.4 & 10.66 & 110.35 & 234 & 126.28 & 73.0 & 112.30 & 9.66 & 111.54 & 105.6 & 112.82 \\
\hline \multirow[t]{3}{*}{7.5} & Water & 4.33 & 86.6 & 3.66 & 84.52 & 7.66 & 79.29 & 122.3 & 66.00 & 54.6 & 84 & 7.66 & 88.45 & 79.0 & 84.40 \\
\hline & AsA & 5.33 & 106.6 & 4.66 & 107.6 & 10 & 103.51 & 214.6 & 115.81 & 65.3 & 100.46 & 9.00 & 103.92 & 101.3 & 108.22 \\
\hline & Toc & 4.66 & 93.2 & 4 & 92.37 & 9 & 93.16 & 151.6 & 81.81 & 62.3 & 95.84 & 8.00 & 92.37 & 86.3 & 92.20 \\
\hline \multirow[t]{3}{*}{11.5} & Water & 2.33 & 46.6 & 2 & 46.18 & 5 & 51.75 & 54.6 & 29.46 & 43.0 & 66.15 & 6.66 & 76.90 & 49.00 & 52.35 \\
\hline & AsA & 3.66 & 73.2 & 3.33 & 76.90 & 6.66 & 68.94 & 118.6 & 64 & 53.3 & 82 & 7.66 & \begin{tabular}{|l|}
88.45 \\
\end{tabular} & 75.00 & 80.12 \\
\hline & Toc & 3.33 & 66.6 & 3 & 69.28 & 6 & 62.11 & 109.3 & 58.98 & 45.3 & 69.69 & 7.66 & 88.45 & 69.6 & 74.35 \\
\hline
\end{tabular}

Table (6) flag leaf area $\left(\mathrm{cm}^{2}\right)$ and grain yield per plant $(\mathrm{g})$ of wheat plant as affected by salinity or antioxidants as well as their combinations in the two growing season

\begin{tabular}{|c|c|c|c|c|c|c|c|c|}
\hline \multirow{3}{*}{\begin{tabular}{|l} 
Characters \\
Salinity \\
$\left(\right.$ dSm $\left.^{-1}\right)$ \\
\end{tabular}} & \multicolumn{8}{|c|}{ Antioxidants (B) } \\
\hline & \multicolumn{4}{|c|}{ Flag leaf area $(\mathrm{cm} 2)$} & \multicolumn{4}{|c|}{ Grain yield per plant $(g)$} \\
\hline & 0 & AsA & A-Toc & $\begin{array}{l}\text { Mean of } \\
\text { salinity }\end{array}$ & 0 & AsA & $\alpha$-Toc & $\begin{array}{l}\text { Mean of } \\
\text { salinity }\end{array}$ \\
\hline \multicolumn{9}{|c|}{ First season } \\
\hline Control (0.12) & 22.137 & 27.593 & 24.910 & 24.880 & 7.227 & 9.370 & 8.597 & 8.398 \\
\hline 7.5 & 14.860 & 26.033 & 19.310 & 20.068 & 6.157 & 7.825 & 6.777 & 6.919 \\
\hline 11.5 & 12.970 & 17.987 & 16.130 & 15.696 & 3.557 & 5.523 & 5.223 & 4.768 \\
\hline Mean of antioxidants & 16.656 & 23.871 & 20.117 & & 5.647 & 7.572 & 6.866 & \\
\hline LSD 5\% & $\begin{array}{c}A \\
0.591\end{array}$ & $\begin{array}{c}\mathrm{B} \\
0.570\end{array}$ & $\begin{array}{c}\mathrm{AB} \\
1.024\end{array}$ & & $\begin{array}{c}\text { A } \\
0.358\end{array}$ & $\begin{array}{c}\mathrm{B} \\
0.3601\end{array}$ & $\begin{array}{c}A B \\
0.6239\end{array}$ & \\
\hline \multicolumn{9}{|c|}{ Second season } \\
\hline Control (0.12) & 24.160 & 29.907 & 25.203 & 26.423 & 7.213 & 9.257 & 8.190 & 8.220 \\
\hline 7.5 & 16.997 & 27.977 & 21.693 & 22.222 & 6.067 & 7.623 & 6.660 & 6.783 \\
\hline 11.5 & 12.163 & 17.680 & 16.313 & 15.386 & 2.970 & 5.447 & 5.167 & 4.528 \\
\hline Mean of antioxidants & 17.773 & 25.188 & 21.070 & & 5.417 & 7.442 & 6.672 & \\
\hline |LSD 5\% & $\begin{array}{c}\mathrm{A} \\
0.930 \\
\end{array}$ & $\begin{array}{c}\mathrm{B} \\
0.924\end{array}$ & $\begin{array}{c}\mathrm{AB} \\
1.612\end{array}$ & & $\begin{array}{c}\mathrm{A} \\
0.321\end{array}$ & $\begin{array}{c}\mathrm{B} \\
0.3227 \\
\end{array}$ & $\begin{array}{c}A B \\
0.5592\end{array}$ & \\
\hline
\end{tabular}

